\title{
Polyphenol Polymerization by an Alternative Oxidative Microbial Enzyme and Characterization of the Biological Activity of Oligomers
}

\author{
Patrizia Di Gennaro $\mathbb{D}^{1}{ }^{1}$ Valentina Sabatini, ${ }^{2,3}$ Silvia Fallarini, ${ }^{4}$ \\ Roberto Pagliarin, ${ }^{3}$ and Guido Sello ${ }^{3}$ \\ ${ }^{1}$ Department of Biotechnology and Biosciences, University of Milano-Bicocca, Piazza della Scienza 2, 20126 Milan, Italy \\ ${ }^{2}$ CRC Materiali Polimerici (LaMPo), Department of Chemistry, University of Milan, Via Golgi 19, 20133 Milan, Italy \\ ${ }^{3}$ Department of Chemistry, University of Milan, Via Golgi 19, 20133 Milan, Italy \\ ${ }^{4}$ Department of Pharmacy, University of Piemonte Orientale, Largo Donegani 2, 28100 Novara, Italy
}

Correspondence should be addressed to Patrizia Di Gennaro; patrizia.digennaro@unimib.it

Received 15 February 2018; Accepted 14 March 2018; Published 23 April 2018

Academic Editor: Dong-Wook Han

Copyright (C) 2018 Patrizia Di Gennaro et al. This is an open access article distributed under the Creative Commons Attribution License, which permits unrestricted use, distribution, and reproduction in any medium, provided the original work is properly cited.

\begin{abstract}
The recombinant catalase-peroxidase HPI from E. coli was used as an alternative enzyme in polymerization reactions for the production of (-) epicatechin oligomers and their biological activity was characterized. The enzyme was prepared in two forms: a purified and an immobilized form. Both were tested for their activity in oxidative polymerization reactions, and their stability and reusability were assessed. The polymerization reactions were followed by SEC-HPLC analyses, and the substrate was completely converted into one or more polymerization products depending on the reactions conditions. Results showed that the utilized conditions allowed for the isolation of some oligomers of different molecular weight: the oligomers containing 6 and 7 units of epicatechin substrate are the heaviest ones. Epicatechin was also used in reactions catalyzed by HRP in the same reaction conditions for comparison. In addition, one selected oligomer obtained by HPI enzyme catalysis was shown to act as in vitro inhibitor of tumor cell growth, like one oligomer deriving from epicatechin by HRP catalysis. These data confirm that epicatechin oligomeric form is more effective than its monomer in biological activity and suggest the use of HPI as an alternative enzyme in reactions for the production of epicatechin oligomers.
\end{abstract}

\section{Introduction}

Phenol polymers are interesting compounds in various applications and their preparation has been pursued since many years [1-4]. More recently, the possibility of having a green alternative to classical catalysis has increased the amount of enzymes utilized in this field. Two different enzyme polymerization mechanisms emerged: the hydrolytic and the oxidative mechanisms. Among oxidative catalysts a special position is covered by plant and fungal enzymes, HRP (Horse Radish Peroxidase), and laccases representing the most used catalysts [5].

Peroxidases perform a broad range of radical-mediated polymerization reactions [5-7]. The reactions take advantage of the ability of peroxidases to catalyze the formation of free radicals that, in the appropriate conditions, undergo spontaneous polymerization [8]. Enzymatic polymerization of phenolic compounds performed by peroxidases mainly from fungal and plant origin has been deeply studied $[5,9-$ 11]. The advantages of phenolic compound polymerization by these enzymes are as follows: the possibility of controlling the polymer structure to modify its characteristics and its solubility by changing the reactant ratio, solvents, and temperature and the easy isolation and purification procedures of the obtained compounds [7, 12-14].

Bacterial peroxidases are much less studied and used. Nevertheless, they can represent another source of enzymebased catalysts. Among these, the catalase-peroxidase HPI 
from Escherichia coli $[15,16]$ is one of the most known members of the class I catalase-peroxidase. These enzymes transform the substances containing the peroxide bond, preferentially hydrogen peroxide to oxygen and water [17-19]. In addition to their catalase activities (with $V \max$ values in the order of 2,000-6,000 U/mg) [20], these enzymes function as broad specificity peroxidases, oxidizing various electron donors, including ABTS and $o$-dianisidine $[5,21,22]$. HPI is an efficient peroxidase with an activity on $o$-dianisidine of $8.3 \mathrm{U} / \mathrm{mg}$ at $\mathrm{pH} 4.25[16,20]$. In a recent paper, its use as a polymerization catalyst has been reported [16].

Polyphenols are an important subset of phenols. Most of them are of natural origin and their functions are mainly related to organism protection through their antioxidant power $[1-3,23]$. The use of biocatalysis is considered a powerful alternative for their polymerization and HRP and laccases have their intensive use $[5,6]$. However, in our knowledge this is the first time that the use of bacterial peroxidases like HPI protein for the polymerization of polyphenol compounds is described. For this, the use of a very convenient and easy-toprepare bacterial peroxidase as HPI in order to make polyphenol polymers could add an important point to its exploitation as a multifaceted catalyst.

Polyphenols have been used in veterinary and human applications. These compounds are known for their broad range of biological activity; they act as anticancer, antiinflammatory, antiallergic, and antiviral agents. In particular, catechins are the most studied compounds also for their ability to regulate the cycle in human cell lines [24-28].

It is also known that oligomers derived from polyphenols are sometimes more effective than the corresponding monomers; therefore, polyphenol polymerization has become a matter of study.

Some preliminary data from Nagarajan et al. suggest that epicatechin polymers obtained by HRP polymerization catalysis could be more effective than the corresponding monomer in tumor cell line growth inhibition [4]. It is thus straightforward to choose epicatechin as the substrate in our experiments to test if the obtained products show a comparable activity.

In this paper the results of polymerization reactions catalyzed by HPI enzyme to obtain polymers of low molecular weight from epicatechin are presented. In addition, it is shown that the obtained oligomers can act, in vitro, as inhibitors of tumor cell growth like oligomers derived from epicatechin by HRP peroxidase catalysis.

\section{Materials and Methods}

2.1. Crude Extract Preparation. E. coli M15[pREP4] (pQE30KATG) strain was grown at $37^{\circ} \mathrm{C}$ in $500 \mathrm{~mL}$ of $\mathrm{LB}$ medium supplemented with ampicillin and kanamycin and $1 \mathrm{mM}$ IPTG as reported by Di Gennaro et al. [16]. After $6 \mathrm{~h}$ from induction at $30^{\circ} \mathrm{C}$, cells were harvested by 10 min centrifugation at $6,000 \mathrm{rpm}$.

A pellet of cells equal to $\mathrm{OD}_{600}=80$ was resuspended in $10 \mathrm{mM}$ phosphate buffer $\mathrm{pH} 7$ and treated with $10 \mathrm{mg} / \mathrm{mL}$ of lysozyme for $30 \mathrm{~min}$ at $4^{\circ} \mathrm{C}$. Then cells were disrupted by sonication (five cycles of $10 \mathrm{~s}$ ). The cell lysate was centrifuged for $30 \mathrm{~min}$ at $12,000 \mathrm{rpm}$ at $4^{\circ} \mathrm{C}$, and the clear supernatant (soluble fraction) was analysed by Bradford method as reported in Di Gennaro et al. [16].

2.2. Enzyme Immobilization. Crude extracts $(120 \mathrm{mg})$ containing the recombinant protein were added to $4 \mathrm{~mL}$ of equilibrated $\mathrm{Co}^{2+}$ affinity resin (Talon ${ }^{\circledR}$, Clontech) and incubated for $20 \mathrm{~min}$ at $4^{\circ} \mathrm{C}$. The resin was stored in the equilibration buffer $\left(\mathrm{Na}_{3} \mathrm{PO}_{4} 50 \mathrm{mM}, \mathrm{NaCl} 300 \mathrm{mM}, \mathrm{pH} 8\right)$ at $4^{\circ} \mathrm{C}$.

2.3. His-HPI Protein Purification. The His-HPI protein purification was performed with the procedure described by $\mathrm{Di}$ Gennaro et al. [16]. The protein concentration of eluted aliquots was determined by Bradford method and a sample of each of the eluted fractions was analysed by electrophoresis on a $10 \%$ SDS-polyacrylamide gel (Novex Bis-Tris Gels 10\%, Invitrogen) and visualized with Comassie Brillant Blue to verify the elution of protein [16]. Imidazole was removed by a membrane dialysis tube with a 12,000 -Da cut-off against $10 \mathrm{mM}$ phosphate buffer $\mathrm{pH} 7$ overnight at $4^{\circ} \mathrm{C}$.

2.4. Peroxidase Activity Assay of HPI. To assess the peroxidase activity of HPI in all its forms we used a standard procedure. Protein sample (containing $0.02 \mathrm{mg} / \mathrm{mL}$ of crude extract or $0.0002 \mathrm{mg} / \mathrm{mL}$ of purified protein) was added to a solution containing $1.0 \mathrm{mM}$ pyrogallol in $10 \mathrm{mM}$ phosphate buffer $\mathrm{pH} 7.0$ and $0.88 \mathrm{mM} \mathrm{H}_{2} \mathrm{O}_{2}$ [15]. Data were normalized using as control a solution containing $1.0 \mathrm{mM}$ pyrogallol in the appropriate phosphate buffer and $0.88 \mathrm{mM} \mathrm{H}_{2} \mathrm{O}_{2}$ without protein addition. All the reactions were carried out at $30^{\circ} \mathrm{C}$ for 4-10 min, and all optical spectra were recorded with a Varian Cary 3 UV-visible spectrophotometer. The molar extinction coefficient was $2640 \mathrm{M}^{-1} \mathrm{~cm}^{-1}$ at $430 \mathrm{~nm}$. The specific activity was determined as $\mu \mathrm{mol} \times \mathrm{mg}^{-1} \times \mathrm{min}^{-1}$.

2.5. Stability of the His-HPI in Different Conditions. All forms of HPI (HPI immobilized to resin, HPI purified enzyme) were tested for time stability measuring peroxidase activity on pyrogallol. Different storage conditions of the $6 \mathrm{x}$ His-HPI protein were used. In particular, different times of storage at 4 and $-20^{\circ} \mathrm{C}$ were used for each form. The activity was determined as reported above.

2.6. Polymerization Reactions. Polymerization reactions were carried out as reported by Di Gennaro et al. [16]. The reactions were performed in a final volume of $2 \mathrm{~mL}$ for test reactions and $10 \mathrm{~mL}$ for preparative reactions with $0.1 \mathrm{mg} / \mathrm{mL}$ of purified HPI protein and $1 \mathrm{mg} / \mathrm{mL}$ of substrate. Polymerization reactions were performed also with HRP enzyme (SigmaAldrich, 150-250 U/mg, salt-free) in the same conditions utilized with HPI. The reactions were initiated by the addition of $\mathrm{H}_{2} \mathrm{O}_{2}$. When the substrate concentration remained constant by HPLC analysis, the reactions were stopped and analysed.

The consumption of the substrate was monitored at $280 \mathrm{~nm}$ by HPLC-RP chromatography, using a reverse phase LC-18 column with $\mathrm{H}_{2} \mathrm{O} / \mathrm{CH}_{3} \mathrm{CN} 80: 20$ at $1 \mathrm{~mL} / \mathrm{min}$ flow. 
In order to perform the analysis of the polymerization products they were isolated. Depending on the reaction products we used a stepwise procedure. In presence of a solid precipitate the suspension was centrifuged $\left(6000 \mathrm{rpm}\right.$, at $\left.4^{\circ} \mathrm{C}\right)$, the supernatant separated, and the solid washed twice with water. The solid was then overnight dried in an oven at $70^{\circ} \mathrm{C}$. The supernatant, as all the solutions directly coming from the reactions, was acidified to $\mathrm{pH} 3$ and extracted three times using a mixture of butanol: ethyl acetate 1:9. The merged organic phases were dried on $\mathrm{Na}_{2} \mathrm{SO}_{4}$ and filtered, and the solvent evaporated at retention time using a gentle $\mathrm{N}_{2}$ flow.

\subsection{Polymerization Product Characterizations}

2.7.1. First Size-Exclusion Analysis (SEC-1). This system has been used to determine the molecular weight (MW) of some samples. The MW has been determined using a SEC system based on a Waters 1515 Isocratic pump, 4 Phenomenex columns (Phenogel $5 \times 10^{-3} \AA-5 \times 10^{-4} \AA-5 \times 10^{-5} \AA-500 \AA$ connected together), and an RI detector or an UV detector. The analyses have been performed at r.t., at $1 \mathrm{~mL} / \mathrm{min}$ solvent (THF) flow and $40 \mu \mathrm{L}$ of sample. Samples were prepared dissolving $1 \mathrm{mg}$ of solid sample in $200 \mu \mathrm{L}$ of THF (HPLC grade). MWs are expressed in polystyrene (PS) equivalents. Calibration has been realized using PS standards, with the following nominal peak molecular weight (MP) and molecular weight distribution $(D)$ values: $\mathrm{Mp}=1600000 \mathrm{Da}(D \leq 1.13)$, $\mathrm{Mp}=1150000 \mathrm{Da}(D \leq 1.09), \mathrm{Mp}=900000 \mathrm{Da}(D \leq 1.06)$, $\mathrm{Mp}=400000 \mathrm{Da}(D \leq 1.06), \mathrm{Mp}=200000 \mathrm{Da}(D \leq 1.05)$, $\mathrm{Mp}=90000 \mathrm{Da}(D \leq 1.04), \mathrm{Mp}=50400 \mathrm{Da}(D=1.03), \mathrm{Mp}$ $=30000 \mathrm{Da}(D=1.06), \mathrm{Mp}=17800 \mathrm{Da}(D=1.03), \mathrm{Mp}=$ $9730 \mathrm{Da}(D=1.03), \mathrm{Mp}=5460 \mathrm{Da}(D=1.03), \mathrm{Mp}=2032 \mathrm{Da}$ $(D=1.06), \mathrm{Mp}=1241 \mathrm{Da}(D=1.07), \mathrm{Mp}=906 \mathrm{Da}(D=$ $1.12)$, and $\mathrm{Mp}=478 \mathrm{Da}(D=1.22)$, with ethyl benzene (PM $=106 \mathrm{~g} / \mathrm{mol}) .1,2$-Dichlorobenzene has been used as internal standard.

2.7.2. Second Size-Exclusion Analysis (SEC-2). This system has been used to calculate the MWs of the remaining products. The MW has been determined using a SEC system based on a Waters 600E pump, a Waters $486 \mathrm{UV}$ detector, and a Phenomenex column (Phenogel $5 \mu, 100 \AA$ ). The analyses have been performed at r.t., at $0.3 \mathrm{~mL} / \mathrm{min}$ solvent (DMF) flow and $20 \mu \mathrm{L}$ of sample. Samples were prepared dissolving $1 \mathrm{mg}$ of solid in $1 \mathrm{~mL}$ of DMF (HPLC grade). The MWs have been calculated from a correlation line prepared using the retention times and MWs of three standards: epicatechin, oligomer at $1588 \mathrm{mu}$, and oligomer at $2038 \mathrm{mu}$. All measures were repeated three times.

2.7.3. MALDI-TOF Analyses. MALDI-TOF analyses were performed using the instrument MALDI-TOF MICROFLEX, Bruker Daltonics. DHB (gentisic acid) has been used as the matrix. Samples were dissolved in $\mathrm{MeOH}$. Two series of peaks have been obtained: 2038-1750-1462-1174-886 and 1570-1282994-706.

\subsection{Biological Activity Tests}

2.8.1. Preparation of Cell Line Cultures. The human A375 and WM 266-4 melanoma cell lines were maintained in DMEM, supplemented with $10 \%$ fetal bovine serum (FBS), $2 \mathrm{mM}$ L-glutamine, $100 \mathrm{U} / \mathrm{mL}$ penicillin, and $100 \mathrm{mg} / \mathrm{mL}$ streptomycin (GE healthcare, Milan, Italy). Twice a week, cells were detached with trypsin/EDTA (GE healthcare), counted, and reseeded in a fresh culture medium at different densities.

2.8.2. Cell Proliferation Determination. Cell proliferation was measured by the 3-(4,5-dimethylthiazol-2-yl)-2,5-diphenyltetrazolium bromide (MTT) assay [23]. A375 or WM 2664 cells were seeded $\left(0.5 \times 10^{5}\right.$ cells/well $)$ in 24 -well plates and treated with increasing concentrations $(0.01-10 \mu \mathrm{g} / \mathrm{mL})$ of each compound for 3 or 6 days at $37^{\circ} \mathrm{C}$ in a $5 \% \mathrm{CO}_{2}$ humidified incubator. The percentage of cell proliferation was calculated as $[100(x-y) /(z-y)]$, where $x, y$, and $z$ were the absorbance read in compound-treated, resting, and compound-untreated cells, respectively.

2.8.3. Cell Cycle Analyses. The cell cycle was analysed by measurement of the cellular DNA content using the fluorescent nucleic acid dye propidium iodide (PI) to identify the proportion of cells that are in each stage of the cell cycle. The assay was carried out using flow cytometry with a fluorescence-activated cell sorter (FACS). A375 or WM266-4 cells were plated in $\mathrm{p} 35$ dish at a density of $5 \times 10^{5}$ cells/dish in serum-free medium. After $24 \mathrm{~h}$ of incubation at $37^{\circ} \mathrm{C}$, cultures were changed to complete medium and $10 \mu \mathrm{g} / \mathrm{mL}$ of each of the compounds was added to the cells. After 3 or 6 days of incubation, cells were trypsinized, pelleted by centrifugation $\left(400 \mathrm{~g}\right.$ for $5 \mathrm{~min}$ ), fixed by $70 \%$ ethanol, and stored at $-20^{\circ} \mathrm{C}$ $\mathrm{O} / \mathrm{N}$. Fixed cells were stained in Tris-buffered saline (TBS) containing $50 \mu \mathrm{g} / \mathrm{mL}$ PI and $10 \mu \mathrm{g} / \mathrm{mL}$ RNase free of DNase. They were incubated in the dark for $1 \mathrm{~h}$ at $4^{\circ} \mathrm{C}$. Cell cycle analysis was performed by FACS (FACSVantage-SE ${ }^{\circledR}$ flow cytometer, BectonDickinson, Milan, Italy) at $488 \mathrm{~nm}$.

2.8.4. Cell Viability. A375 or WM266-4 cells were labelled with $1 \mathrm{mM}$ Calcein-AM (CAM) (Molecular Probes, Invitrogen) in serum-free PBS for $15 \mathrm{~min}$ at $37^{\circ} \mathrm{C}$ in the dark. After being washed, labelled cells were seeded in 24 -well plates and allowed to adhere overnight at $37^{\circ} \mathrm{C}$ in a humidified incubator. Then, cells were treated with $10 \mu \mathrm{g} / \mathrm{mL}$ of each of the compounds for 6 days at $37^{\circ} \mathrm{C}$ in a $5 \% \mathrm{CO}_{2}$ humidified incubator. After incubation the cells of each well were harvested, washed, and labelled with propidium iodide (PI), and the viability was measured by flow cytometry. Live cells were identified as CAMhigh/PI- population, apoptotic cells were CAMlow, and late apoptotic/necrotic cells were CAMlow/PI+. The percentage of live, apoptotic, and late apoptotic/necrotic cells were calculated by FACSDiva software and expressed as the percentage of CAMhigh/PI-, CAMlow, and CAMlow/PI+ population relative to untreated cells.

2.9. Statistical Analysis. Results were expressed as means \pm SEM of at least three experiments. Statistical significance was evaluated by the one-way ANOVA followed by Student's $t$-test for paired populations, using GraphPad Prism 4 (GraphPad Software, Inc., San Diego, CA, USA). Differences among means were considered significant when $p \leq 0.05$. 
<smiles>O=c1cccc2c(O)c1C(O)=C(O)C(O)=C2</smiles>

FIgURE 1: Dimerization of pyrogallol catalyzed by peroxidases.

\section{Results}

3.1. $6 x$ His-HPI Preparation from E. coli M15[pREP4] ( $p Q E 30$ KATG) Crude Extract. To purify the 6x His-HPI recombinant protein, the E. coli M15[pREP4] (pQE30-KATG) strain was used. The crude extract was prepared and purified as described in a previous paper by Di Gennaro et al. [16]. The fractions were stored at $-20^{\circ} \mathrm{C}$. To prepare the HPI enzyme immobilized to resin, the enzyme loaded resin was stored in the equilibration buffer; samples were stored at $4^{\circ} \mathrm{C}$ and were added to reaction solutions when needed.

3.2. HPI Peroxidase Activity. HPI activity is usually measured using $O$-dianisidine as the reference substrate [15]; however, in our experience $o$-dianisidine cannot be used to measure the activity of the immobilized HPI because it is irreversibly adsorbed by the resin. In order to have a common substrate to measure and compare enzyme activity in all its forms, pyrogallol was selected as the reference substrate. Pyrogallol can be oxidized to purpurogallin by peroxidases (Figure 1). The HPI activity on pyrogallol was measured in the presence of the enzymatic crude extract and in the presence of both the enzyme immobilized on IMAC-Co ${ }^{2+}$ resin and the purified enzyme. The crude extract showed an activity on pyrogallol of $2.5 \times 10^{-1} \mu \mathrm{mol} \times \mathrm{mg}^{-1} \times \mathrm{min}^{-1}$. The activity of the crude extract when conserved at $4^{\circ} \mathrm{C}$ significantly decreases after 28 days to $3.0 \times 10^{-2} \mu \mathrm{mol} \times \mathrm{mg}^{-1} \times \mathrm{min}^{-1}$; in contrast, when conserved at $-20^{\circ} \mathrm{C}$ it remains more or less constant over two months. This permits the use of the extract without needing a fresh preparation.

In order to have the biocatalyst in a form easy to manage and recycle, the same resin used for its purification (IMAC $\mathrm{Co}^{2+}$ ) was used for its immobilization. Although this operation is fast and selective, it was necessary to test both the enzyme activity and the stability of the enzyme in this form. So, we performed preliminary activity tests on the immobilized HPI form using pyrogallol as the reference substrate in different experimental conditions. Initially, the conditions used to perform the enzyme immobilization were phosphate buffer $50 \mathrm{mM}$ at $\mathrm{pH} 8$ with $\mathrm{NaCl} 1.8 \%$; but at $\mathrm{pH} 8$ pyrogallol spontaneously dimerizes and therefore a different set of conditions was selected. The results showed that $\mathrm{pH} 6.5$ and $\mathrm{NaCl}$ at $0.3 \%$ are the best conditions for the activity of immobilized HPI on pyrogallol $\left(4.5 \times 10^{-1} \mu \mathrm{mol} \times \mathrm{mg}^{-1} \times\right.$ $\left.\min ^{-1}\right)$; in these conditions the pure resin is inactive. Then, activity retention tests of the enzyme in this form were performed during the time. The enzyme immobilized onto the resin (enzymatic resin hereafter) cannot be frozen because the resin itself does not maintain its characteristics. Therefore,
TABLE 1: Specific activity of HPI on resin on pyrogallol at $4^{\circ} \mathrm{C} .{ }^{a}$

\begin{tabular}{lc}
\hline Time & Specific activity \\
\hline $1 \mathrm{~d}$ & $2.0 * 10^{-1} \pm 2.2 * 10^{-2}$ \\
$31 \mathrm{~d}$ & $4.5 * 10^{-1} \pm 1.3 * 10^{-1}$ \\
$41 \mathrm{~d}$ & $5.4 * 10^{-1} \pm 5.6 * 10^{-2}$ \\
$58 \mathrm{~d}$ & $2.6 * 10^{-1} \pm 9.0 * 10^{-2}$ \\
$121 \mathrm{~d}$ & $3.2 * 10^{-1} \pm 4.7 * 10^{-2}$ \\
\hline${ }^{\mathrm{a}} \mu \mathrm{mol} \mathrm{min}^{-1} \mathrm{mg}^{-1}$ &
\end{tabular}

the tests were performed using enzymatic resin conserved at $4^{\circ} \mathrm{C}$ in the equilibration buffer $50 \mathrm{mM}$ phosphate buffer at $\mathrm{pH} 8$ and with $1.8 \% \mathrm{NaCl}$; reactions were performed in the reference conditions. Results showed that the enzyme preserves its activity even after two months (Table 1; value variations are ascribed to the approximation in the resin amount used in each experiment series).

The specific activity referred to pyrogallol oxidation of the immobilized enzyme $\left(0.45 \mu \mathrm{mol} \times \mathrm{mg}^{-1} \times \mathrm{min}^{-1}\right)$ is nearly twice as high as that of the enzyme in the crude extract $\left(0.23 \mu \mathrm{mol} \times \mathrm{mg}^{-1} \times \mathrm{min}^{-1}\right)$. In a parallel series of tests the activity and the activity retention of the purified enzyme were checked. The specific activity of the purified HPI $(0.17 \mu \mathrm{mol}$ $\left.\times \mathrm{mg}^{-1} \times \mathrm{min}^{-1}\right)$ is 2.5 times lower than that of the enzymatic resin. In addition, HPI activity is halved after one-month con servation in the equilibration buffer both at $4^{\circ} \mathrm{C}$ and at $-20^{\circ} \mathrm{C}$. This result showed that the immobilized HPI is much more stable than the purified enzyme in similar conditions and that it can be stored for more than 2 months at $4^{\circ} \mathrm{C}$ without loss of activity. Furthermore, the resin form can be easily used several times showing similar efficiency (data not shown).

3.3. Epicatechin Polymerization Reactions. Catechins are the principal structural units in condensed tannins. They belong to the group of the 3-flavanols and are present in many varieties of vegetables, herbs, and tees. They are active as preventive of cancer and of inflammatory and cardiovascular diseases, because of their antioxidant action that can limit and remove free radicals [29]. It is also known that in the form of oligomers their activity can be enhanced [4]. To this end, the possibility of substituting the commonly used HRP (Horse Radish Peroxidase) of vegetal origin with the microbial HPI in polymerization reactions was investigated. The polymerization of a catechin as the (-) epicatechin was initially performed in different reaction conditions using HRP as reference. The reaction was followed by the consumption of the substrate that was monitored by HPLC at $280 \mathrm{~nm}$. In all the tested conditions the amount of consumed (-) epicatechin was over the $90 \%$ up to a concentration of $3.44 \mathrm{mM}$ in the reaction.

Then, epicatechin polymerization was performed in the same conditions utilized for HRP using the recombinant enzyme HPI (from E. coli M15(pREP4) (pQE30-katG)), immobilized onto the IMAC resin. Also, in this case, the decrease of the substrate was monitored by HPLC. The substrate was always completely consumed, except when using a high concentration of epicatechin (17.2 mM) (Table 2). Finally, 
TABLE 2: Epicatechin consumed by immobilized HPI in different reaction conditions.

\begin{tabular}{lccc}
\hline Reaction conditions & $\mathrm{H}_{2} \mathrm{O}_{2}(\mathrm{mM})$ & Enzyme $(\mathrm{mg} / \mathrm{mL})$ & Consumed epicatechin \\
\hline Epicatechin 3.44 mM + EtOH 5\% & 15.5 & 0.00 & No reaction \\
Epicatechin $0.69 \mathrm{mM}+$ EtOH 20\% & 11.2 & 0.01 & $>90 \%$ \\
Epicatechin 3.44 mM + EtOH 5\% & 15.5 & 0.01 & $>90 \%$ \\
Epicatechin 3.44 mM + EtOH 30\% & 8.8 & 0.01 & $>90 \%$ \\
Epicatechin $17.2 \mathrm{mM}+$ EtOH 30\% & 52.9 & 0.01 & $>25 \%$ \\
\hline
\end{tabular}

TABLE 3: Epicatechin consumed by purified HPI.

\begin{tabular}{lc}
\hline $\mathrm{H}_{2} \mathrm{O}_{2}$ additions & Consumed epicatechin \\
\hline $0[0.0 \mathrm{mM}]$ & $0 \%$ \\
$1[3.9 \mathrm{mM}]$ & $31 \%$ \\
$2[7.8 \mathrm{mM}]$ & $31 \%$ \\
$3[11.7 \mathrm{mM}]$ & $33 \%$ \\
$4[15.6 \mathrm{mM}]$ & $48 \%$ \\
$5[19.5 \mathrm{mM}]$ & $48 \%$ \\
$6[23.4 \mathrm{mM}]$ & $50 \%$ \\
$7[27.3 \mathrm{mM}]$ & $50 \%$ \\
$8[31.2 \mathrm{mM}]$ & $57 \%$ \\
$9[35.1 \mathrm{mM}]$ & $57 \%$
\end{tabular}

experiments have been performed using the purified free enzyme HPI. As it is shown in Table 3 , the substrate was only partially consumed $(60 \%)$ even in the presence of a high concentration of protein $(0.12 \mathrm{mg} / \mathrm{mL}$; i.e., 12 times the amount present in the experiments with enzymatic resin). Results indicated that HPI can be considered a good biocatalyst in the epicatechin polymerization only in the immobilized form.

3.4. Product Analysis and Characterization. To perform the analysis of the polymerization products their preliminary isolation was studied. The formed oligomers are differently soluble in water and they partially precipitate. Because during filtration the oligomers are easily adsorbed on the filters, a procedure that contemplates two steps was used: first, the separation of the solid by centrifugation and, second, the extraction of the water phase with an organic mixture (butanol: ethyl acetate). In addition, the solvent evaporation should be made with care, to preserve the integrity of the products.

The identification of the epicatechin oligomers produced by the biocatalysts required the following procedure. One product was characterized using Maldi mass analysis. Two compounds were then analysed using a first SEC chromatography system; this analysis confirmed Maldi result through system calibration and gave a second product weight. Finally, all the products were analysed using a second SEC chromatography system; using retention times of this analysis and the MWs calculated using the previous analyses a correlation line between retention times and molecular weights was prepared.

Maldi mass analysis clearly shows two sets of peaks. The first set has its highest MW at 2038 mass units, followed by a regular series of peaks each separated by 288 mass units

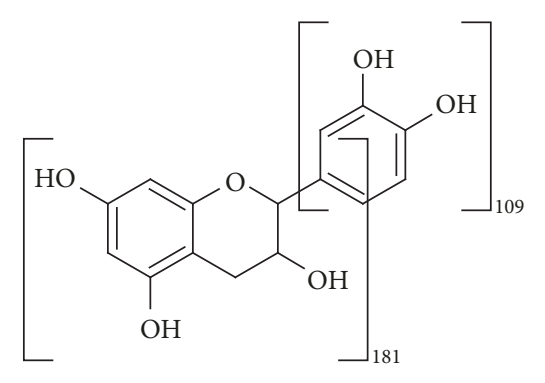

FIGURE 2: Fragmentation of epicatechin.

(epicatechin monomer); the second set has its highest MW at 1570 mass units, also followed by a regular series of peaks each separated by 288 mass units. The first series corresponds to a 7-unit oligomer; the second series corresponds to a 6unit oligomer that lost a group weighting 180 units. This last weight corresponds to the loss of the bicyclic part of epicatechin. At this analysis level it cannot be stated if the second series derives from a self-standing oligomer or from the mass analysis evolution.

In the first SEC analysis the compound MW was estimated using a polystyrene (PS) based calibration; this permits the calculation of an MW of 2326 for the compound used in the Maldi analysis and of an MW of 1724 for a second compound, selected for its well defined difference in chromatography retention time. Using these two MWs and epicatechin as reference, a correlation line between retention time and MW was prepared using the second SEC system. Then, we completed the analysis of the remaining compounds; the results are reported in Table 4. The reaction conditions used to prepare the analysed compounds are reported in Table 5 .

Maldi and SEC analyses confirmed the presence of two oligomers that lost the bicyclic part of epicatechin (Figure 2).

3.5. Effect of Epicatechin and of Oligomers from Epicatechin by HPI and by HRP on Melanoma Cell Line Proliferation. Since catechins have been demonstrated to inhibit tumor cell line growth $[2,4,30]$, the effect of epicatechin (EC) and one of the oligomers from epicatechin by HPI (called polymer A of 7 units of epicatechin) and one of the oligomers by HRP (called polymer B of 7 units of epicatechin) was first evaluated on melanoma cell line proliferation by MTT assay. As shown in Figure 3 the treatment (6 days) of WM266-4 cell line with $10 \mu \mathrm{g} / \mathrm{mL}$ of polymer A or polymer B resulted in a slight but significant $(p<0.05)$ inhibition $(-18 \%$ and -15 for polymer A and polymer B, resp.) of cell proliferation. Differently, the treatment (6 days) of A375 cell line induced 
TABLE 4: MW of the obtained oligomers.

\begin{tabular}{|c|c|c|c|c|c|}
\hline Compound & Retention time $\mathrm{a}^{\mathrm{a}}$ & Measured $\mathrm{MW}^{\mathrm{b}}$ & Calculated $\mathrm{MW}^{\mathrm{c}}$ & Units $^{\mathrm{d}}$ & Enzyme \\
\hline epicatechin & 10.17 & $331^{\mathrm{e}}$ & & 1 & \\
\hline P1 & 6.80 & 2326 & 2038 & 7 & HRP \\
\hline $\mathrm{P} 2$ & 7.33 & & 1520 & $6^{\mathrm{f}}$ & HPI \\
\hline P3 & 7.32 & 1724 & 1529 & $6^{\mathrm{f}}$ & HRP \\
\hline P4 & 6.94 & & 1885 & $7^{\mathrm{f}}$ & HRP \\
\hline P5 & 6.95 & & 1875 & $7^{\mathrm{f}}$ & HPI \\
\hline P6 & 6.89 & & 1937 & 7 & HPI \\
\hline
\end{tabular}

${ }^{\mathrm{a}}$ Measured using SEC-2 system. ${ }^{\mathrm{b}}$ Calculated using SEC-1 system. ${ }^{\mathrm{c}}$ From the correlation line. ${ }^{\mathrm{d}}$ Number of epicatechin units. ${ }^{\mathrm{e}}$ Corrected weight using Maldi/SEC ratio. ${ }^{\mathrm{f}}$ From the compound that lost the bicyclic part.

TABLE 5: Conditions of reaction utilized for the obtained oligomers.

\begin{tabular}{|c|c|c|c|c|}
\hline Compound & Conc. EPI & Enz. & $\mathrm{EtOH}$ & $\mathrm{mL}^{\mathrm{a}}$ \\
\hline $\mathrm{P} 1$ & $3.44 \mathrm{mM}$ & $1 \mathrm{mg}$ HRP & $20 \%$ & 20 \\
\hline $\mathrm{P} 2^{\mathrm{b}}$ & $3.44 \mathrm{mM}$ & $0.01 \mathrm{mg}$ HPI & $5 \%$ & 1 \\
\hline P3 & $3.44 \mathrm{mM}$ & $0.01 \mathrm{mg}$ HRP & $5 \%$ & 1 \\
\hline $\mathrm{P} 4$ & $3.44 \mathrm{mM}$ & $0.01 \mathrm{mg}$ HRP & $5 \%$ & 20 \\
\hline P5 & $0.69 \mathrm{mM}$ & $0.05 \mathrm{mg}$ HPI & $20 \%$ & 2.5 \\
\hline $\mathrm{P}^{\mathrm{c}}$ & $3.44 \mathrm{mM}$ & $0.01 \mathrm{mg}$ HPI & $5 \%$ & 1 \\
\hline
\end{tabular}

${ }^{a}$ Reaction volume. ${ }^{\mathrm{b}} 3 \mathrm{~mL}$ of $\mathrm{H}_{2} \mathrm{O}_{2}$ added. ${ }^{\mathrm{c}} 42 \mathrm{~mL}$ of $\mathrm{H}_{2} \mathrm{O}_{2}$ added.

a significant $(p<0.05)$ concentration dependent reduction of proliferation with a maximum of $-28 \%$ and $-21 \%$, at $10 \mu \mathrm{g} / \mathrm{mL}$ for polymer $\mathrm{A}$ and polymer $\mathrm{B}$, respectively. In contrast, no effect was observed for EC on both cell lines at any tested concentrations and times.

3.6. Effect of EC, Polymer A, and Polymer B on Melanoma Cell Cycle. To further investigate the mechanism by which polymer A and polymer B affect melanoma cell line proliferation, the cell cycle was analysed. A375 or WM266-4 cells were treated with the compound and were shown to be active on both cell lines in the proliferation assay $(10 \mu \mathrm{g} / \mathrm{mL})$ for 6 days and the distributions on cell cycle analysed by flow cytometry. As shown by PI staining, exposure to polymer A and polymer B (Figure 4) induced similar effects on both cell lines, an increase in the cell number in the G0/G1 phases $(+22 \%$ and $+17 \%$, resp., for $\mathrm{A} 375$ cells; $+25 \%$ and $+20 \%$, resp., for WM266- 4 cells) accompanied by a reduction of cell number in S and G2 phases when compared with control cells, indicating an arrest in G0/G1 phases in cell cycle progression. Moreover a slight increase in debris was observed with both polymer A and polymer B. EC treatment did not induce any significant alteration in WM266-4 and A375 cells.

3.7. Effects of EC, Polymer A, and Polymer B on Cell Viability. To evaluate whether tested compounds exert also cytotoxic effects on tumor cells a CAM assay was performed. CAM labelled A375 and WM26-4 were treated (6 days) with $10 \mu \mathrm{g} / \mathrm{mL}$ of each compound, counterstained with PI and analysed by FACS. As shown in Figure 5 both polymer A and polymer B induced an increase in CAM negative cells (apoptotic cells) (+26\% and $+20 \%$, resp., for A375 cells; $+15 \%$ and $+23 \%$, resp., for WM266- 4 cells), and a slight increase in $\mathrm{CAM}^{-} / \mathrm{PI}^{+}$cells (necrotic/late apoptotic cells). Conversely no significant cell death was observed in cell treated with EC.

\section{Discussion}

The interest towards enzymatic polymerization reactions catalyzed by peroxidases is growing, because they can be considered a valid alternative to chemical catalysis $[5,6,12$, 17]. Besides hydrolytic enzymes, oxidative enzymes represent a significant portion of these catalysts; in particular, fungal and plant oxidative enzymes are often used, while bacterial oxidative enzymes are still quite rare. However, enzymes from bacteria are easier to prepare because they are easily cultivated and many efficient procedures for their genetic manipulation have become standard in biomolecular studies. Consequently, the possibility of substituting enzymes of other origins with microbial alternatives is of great interest. Oxidative metal enzymes are widespread in bacteria. An issue in enzyme-mediated oxidative polymerizations is the number and variety of accepted substrates. Often, simple substrates (e.g., phenols) are easily transformed, while more complex ones (e.g., polyphenols) cannot be used.

E. coli HPI is a potential oxidative biocatalyst because it has both catalase and peroxidase activity [31, 32]. HPI is a metal based enzyme, containing Fe(II) in its catalytic site and its activity is connected to the oxidation state changes of iron. In the case of HPI it is also known that its catalase activity takes place at the iron site. Hydrogen peroxide is a small molecule that can easily penetrate the enzyme reaching the metal site. The issue becomes more complex when considering molecules of bigger size (as epicatechin) and growing polymers. In this paper, a recombinant HPI enzyme from $E$. coli was used in two different forms: the enzyme immobilized on the IMAC resin and the purified enzyme. All the preparations are active in test oxidative experiments, showing negligible differences. In contrast, the activity retention is different depending on the preparation. The enzyme immobilized on the resin is still fully active after two months, when it is conserved at $4^{\circ} \mathrm{C}$. The free enzyme fast loses its activity at both $4^{\circ} \mathrm{C}$ and $-20^{\circ} \mathrm{C}$. This different behaviour can be explained considering the enzyme specific form. When it is blocked on the resin the enzyme resides inside the polymeric support; as a consequence, its $3 \mathrm{D}$ structure is stabilized and the activity 


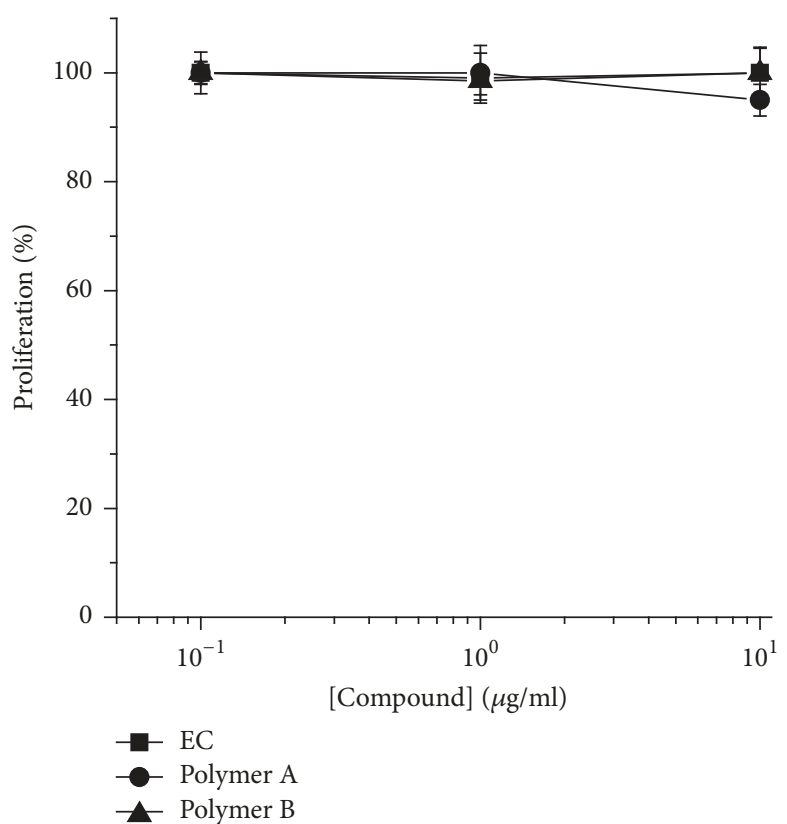

(a)

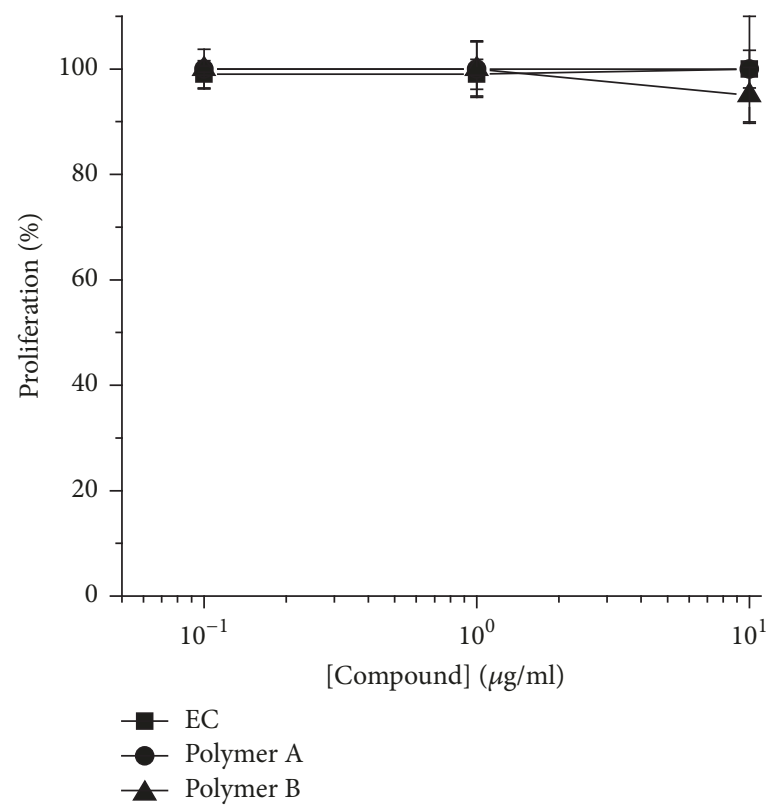

(c)

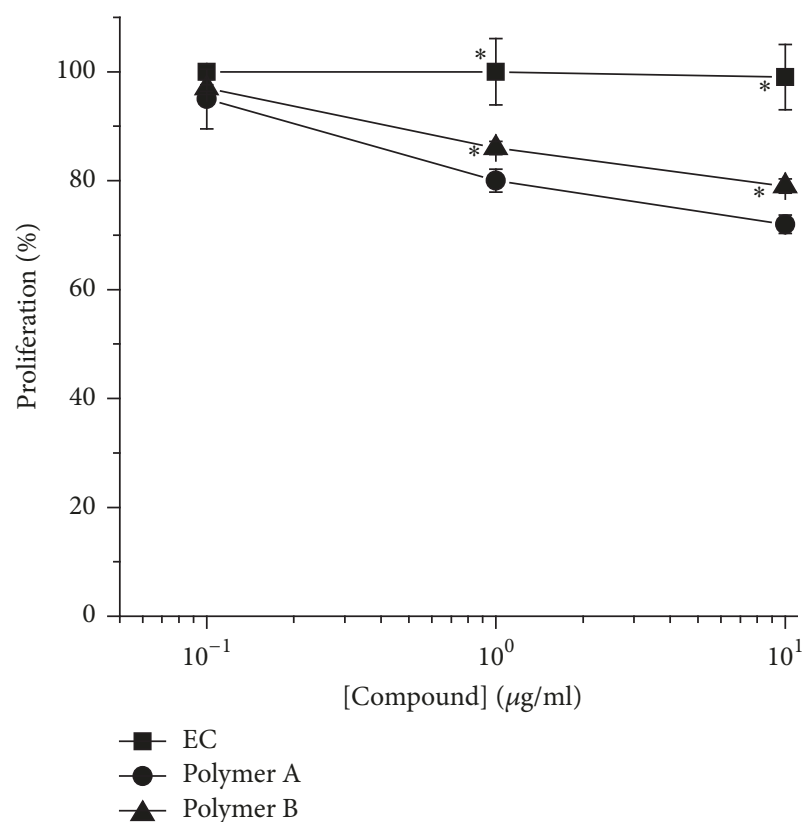

(b)

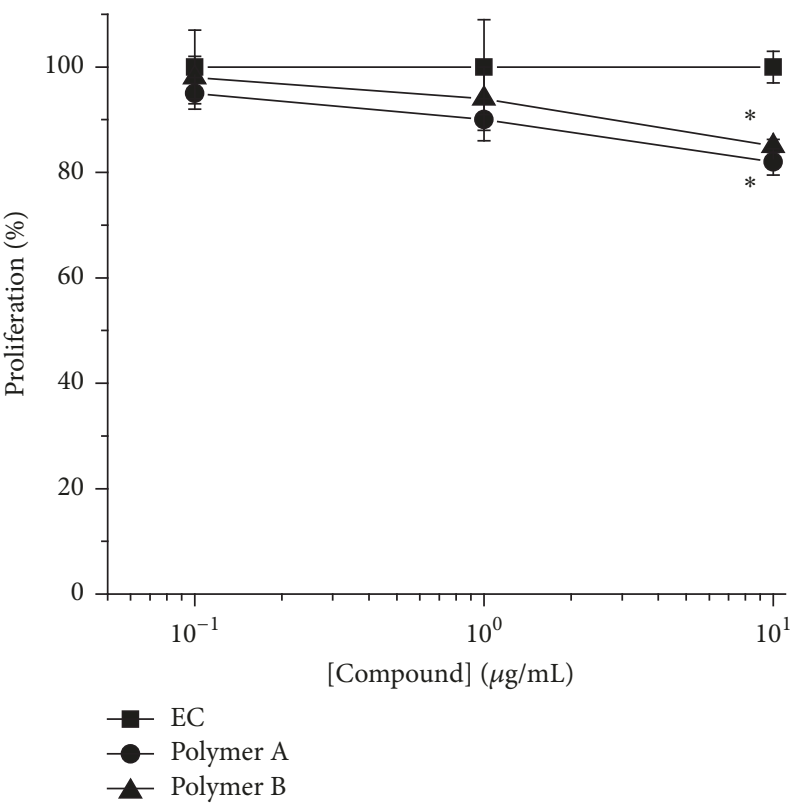

(d)

FIGURE 3: Oligomers effects on A375 ( $\mathrm{a}$ and b) and WM266-4 ( $\mathrm{c}$ and d) proliferation. Cells were treated with increasing concentrations $(0.1-10 \mu \mathrm{g} / \mathrm{ml}$ ) of polymers A and B or EC for 3 (a and c) and 6 days (b and d). Cell proliferation was analysed by 3-(4,5-dimethylthiazol-2yl)-2,5-diphenyl-tetrazolium bromide (MTT) assay and results were expressed as mean of percentage of the number of cells with respect to control cells. Data are shown as mean \pm SEM. ${ }^{*} p<0.05$.

is maintained for long time. Here, the temperature is less important. When in the free form, the enzyme is subjected to the solvent effect without any stabilization; thus, it tends to lose its native conformation showing an overall loss of activity. In conclusion, the enzymatic resin is both active and stable; in addition, it can be used several times.

In a previous work HPI was used in polymerization reactions of some aromatic substrates [16]. Results confirmed that the enzyme can act as a catalyst in oxidative polymerizations. Depending on the substrate the prepared oligomers had a specific length; however, the use of polyphenols as substrate was still to be tested. In addition, from the literature it is known that HRP can be used to prepare oligomers of catechins that can be interesting for their biological activity [4]. Everything considered, it is interesting to test the use of HPI for the preparation of (-)-epicatechin oligomers. 


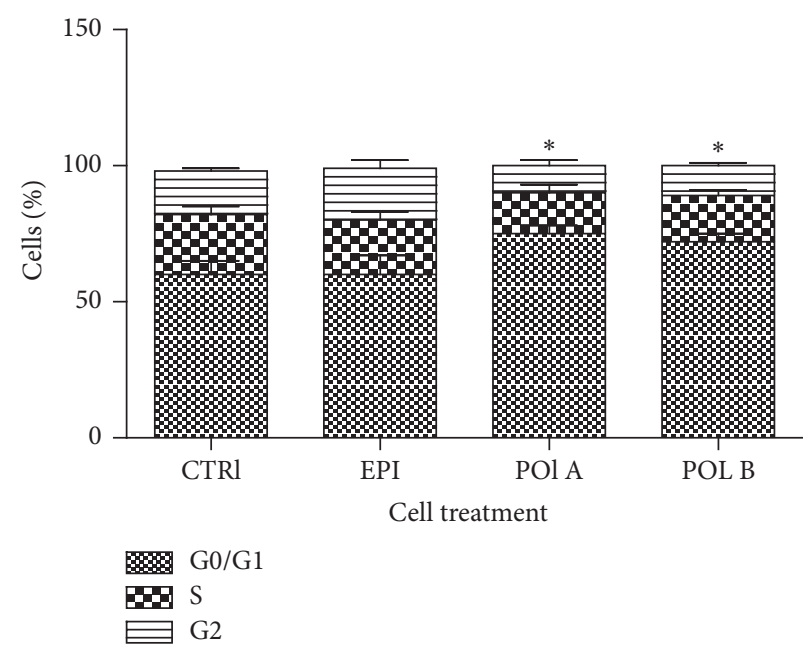

(a)

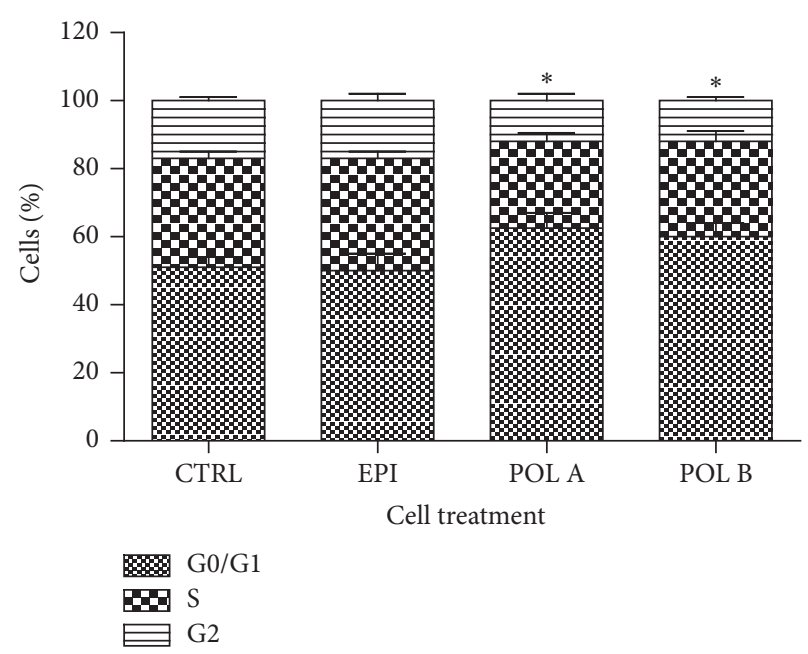

(b)

FIGURE 4: Oligomers effects on A375 (a) and WM266-4 (b) cell cycle. Cells were treated (10 $\mu \mathrm{g} / \mathrm{ml})$ with polymers A and B or EC for 6 days and cell cycle was analysed by fluorescence-activated cell sorter (FACS). Results are expressed as percentage of the cell population in each phase. Data are shown as mean \pm SEM (standard error of mean). ${ }^{*} p<0.05$.

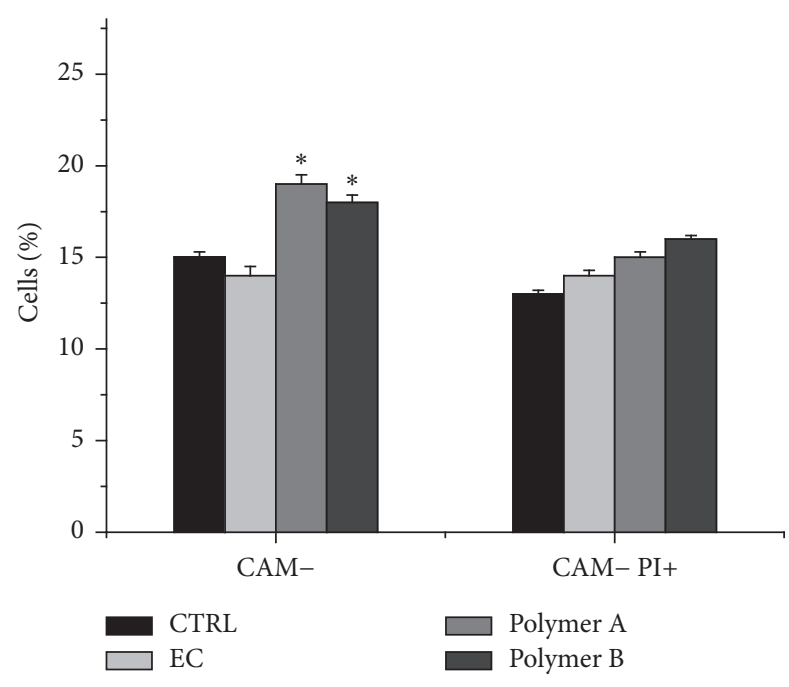

(a)

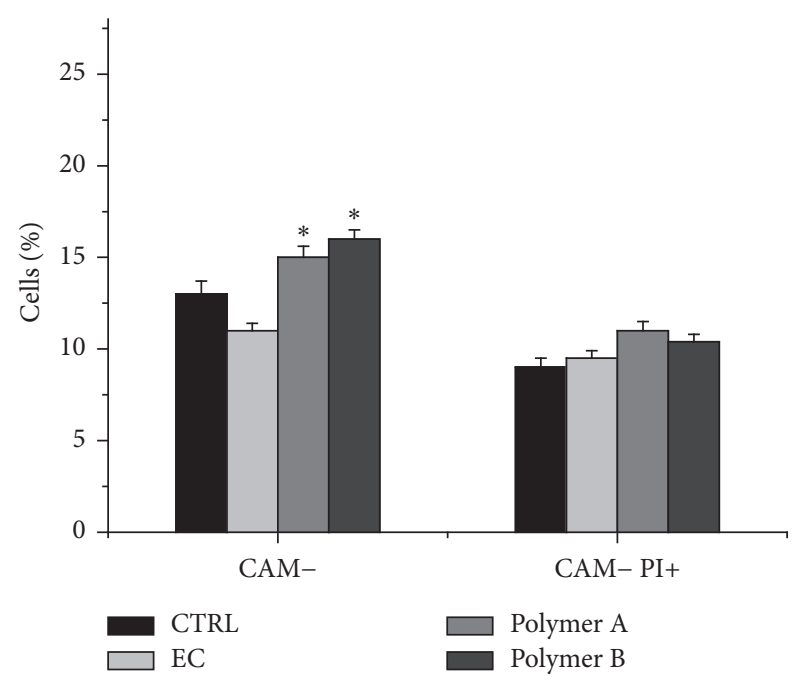

(b)

Figure 5: Oligomers effects on A375 (a) and WM266-4 (b) viability. Cells were treated with polymers A and B or EC (10 $\mu$ g/ml) for 6 days and cell death was analysed by fluorescence-activated cell sorter (FACS). Results are expressed as percentage of apoptotic and late apoptotic/necrotic cells in all samples. Data are shown as mean \pm SEM. ${ }^{*} p<0.05$. CAM- identifies apoptotic cells (Calcein-AMlow) and CAM- PI+ identifies late apoptotic/necrotic cells (Calcein-AMlow, propidium iodide treated).

Experiments with different combinations of conditions to obtain different epicatechin polymers were performed, and this was also done using HRP, to have a comparison. Results demonstrated that reactions performed with HRP or HPI completely consumed the substrate in line with literature data [4]. However, the oligomer length depends on several factors; the most important ones are the number of the started polymerization chains and their lifetime. Decreasing the substrate/enzyme ratio a smaller number of chains are activated and if their lifetime is long enough, the produced oligomer is longer. In contrast, because the polymerization is sustained by the oxidation state of the catalyst, decreasing the $\mathrm{H}_{2} \mathrm{O}_{2}$ concentration decreases the lifetime of the chain that therefore gives shorter oligomers (compare products of experiments P2 and P6) (Tables 4 and 5). The availability of the $\mathrm{H}_{2} \mathrm{O}_{2}$ is influenced by the competition of the two HPI activities: the catalase and the peroxidase ones. Finally, the insoluble product obtained in one experiment lost part of one epicatechin unit. This can be related to the mechanism of chain termination that can derive from a hydrogen loss or gain, or from a molecule part loss. When using the enzyme resin the product resembles that of the insoluble product 
from HRP; this seems to confirm that the chain termination is different in solution or in solid phase.

In conclusion of this part, it is possible to state that HPI in the immobilized form can be used to catalyze polyphenol polymerization; that it is a stable catalyst; and that it can be used several times without losing its activity. In comparison to HRP, obtained products are similar and HPI can be considered a valuable alternative.

The last part of the present study concerns the biological activity of the prepared oligomers.

The biological tests have been performed on two samples (one from HRP and one from HPI, called polymers A and B, resp.) chosen because they have the same length. Oligomer samples used in this study were purified before testing and their biological activity was investigated on the proliferation cell cycle. In both utilized cell lines, exposure to oligomers induced a reduction in tumor cell proliferation. The reduction in cell proliferation was primarily due to an arrest of the cell cycle in G0/G1 phase with a concurrent reduction in S phase. As shown by viability evaluation as a result of cell cycle arrest some cells undergo apoptosis. The ability of many catechins to inhibit tumor cell proliferation or exert cytotoxicity is well documented in many in vitro tumor models. As reported in literature catechins can differently affect tumor cell lines depending on their structure and on dose and time of treatment and type of intracellular trafficking in the cells $[27,33]$. However, some authors suggest that also the degree of polymerization can affect catechin efficacy; in fact, Pierini et al. [34] showed that nongalloylated flavan-3-ols applederived monomer and dimers do not affect tumor cells proliferation and viability, while the oligomers and polymers are effective. Agarwal et al. [35] observed a correlation between the degree of polymerization and the antiproliferative activity on prostate cancer cell lines. We have not observed any effect on cell proliferation, viability, and cell cycle with epicatechin in our tumor models differently with respect to what was reported in literature on catechin as EGCG effects on human fibrosarcoma cells [33]. These results could depend on the tumor cell line selected; in fact literature analysis reveals that the epicatechin effects are dependent on selected tumor cells $[2,3]$; another explanation could be the low concentrations utilized when compared with that which was shown to be active in other models $[23,30]$.

The overall results are consistent with others reported in the literature [4] where the same kinds of oligomers with a similar biological activity were obtained. The novelty of this work is that an alternative enzyme as HPI versus HRP can be used to prepare oligomers (A and B). Moreover, in this paper we demonstrated that the oligomeric forms of epicatechin are more effective than its monomer in the reduction of tumoral cell proliferation and that the reduction in cell proliferation was primarily due to an arrest of the cell cycle in G0/G1 phase with a concurrent reduction in $\mathrm{S}$ phase.

\section{Conclusions}

In conclusion, HPI enzyme can be considered a valuable alternative to vegetal derived enzymes in the preparation of (-)-epicatechin oligomers with a biological activity against tumor proliferation. Even if much work is still to be done, HPI can represent a good biocatalyst and epicatechin oligomers merit some attention as antitumoral agents.

\section{Data Availability}

The data used to support the findings of this study are available from the corresponding author upon request.

\section{Ethical Approval}

All procedures performed in this study were in compliance with Ethical Standards.

\section{Conflicts of Interest}

All the Authors declare that they have no conflicts of interest.

\section{Acknowledgments}

This work has been supported by US-ARMY-Grant no W911NF-10-1-0204 and by PRIN Project 2010-2014 financed by MIUR. The authors thank their students Emanuele Colombo and Sara Danelli for their collaboration in the experiments and Dr. Anna Daghetti for her technical support.

\section{References}

[1] L. A. Mitscher, M. Jung, D. Shankel, J.-H. Dou, L. Steele, and S. P. Pillai, "Chemoprotection: A review of the potential therapeutic antioxidant properties of green tea (Camellia sinensis) and certain of its constituents," Medicinal Research Reviews, vol. 17, no. 4, pp. 327-365, 1997.

[2] X. Tan, D. Hu, S. Li, Y. Han, Y. Zhang, and D. Zhou, "Differences of four catechins in cell cycle arrest and induction of apoptosis in LoVo cells," Cancer Letters, vol. 158, no. 1, pp. 1-6, 2000.

[3] H. R. Siddique, D. J. Liao, S. K. Mishra et al., "Epicatechin-rich cocoa polyphenol inhibits Kras-activated pancreatic ductal carcinoma cell growth in vitro and in a mouse model," International Journal of Cancer, vol. 131, no. 7, pp. 1720-1731, 2012.

[4] S. Nagarajan, R. Nagarajan, S. J. Braunhut et al., "Biocatalytically oligomerized epicatechin with potent and specific antiproliferative activity for human breast cancer cells," Molecules, vol. 13, no. 11, pp. 2704-2716, 2008.

[5] H. Uyama, N. Maruichi, H. Tonami, and S. Kobayashi, "Peroxidase-catalyzed oxidative polymerization of bisphenols," Biomacromolecules, vol. 3, no. 1, pp. 187-193, 2002.

[6] S. Kobayashi, H. Uyama, and S. Kimura, "Enzymatic polymerization," Chemical Reviews, vol. 101, no. 12, pp. 3793-3818, 2001.

[7] Y. H. Kim, E. S. An, B. K. Song, D. S. Kim, and R. Chelikani, "Polymerization of cardanol using soybean peroxidase and its potential application as anti-biofilm coating material," Biotechnology Letters, vol. 25, no. 18, pp. 1521-1524, 2003.

[8] C. Regalado, B. E. García-Almendárez, and M. A. DuarteVázquez, "Biotechnological applications of peroxidases," Phytochemistry Reviews, vol. 3, no. 1-2, pp. 243-256, 2004.

[9] Z. Xia, T. Yoshida, and M. Funaoka, "Enzymatic synthesis of polyphenols from highly phenolic lignin-based polymers (lignophenols)," Biotechnology Letters, vol. 25, no. 1, pp. 9-12, 2003. 
[10] A. Cui, A. Singh, and D. L. Kaplan, "Enzyme-based molecular imprinting with metals," Biomacromolecules, vol. 3, no. 6, pp. 1353-1358, 2002.

[11] S. K. Sahoo, W. Liu, L. A. Samuelson, J. Kumar, and A. L. Cholli, "Biocatalytic polymerization of p-cresol: An in-situ NMR approach to understand the coupling mechanism," Macromolecules, vol. 35, no. 27, pp. 9990-9998, 2002.

[12] S. Kobayashi and A. Makino, "Enzymatic polymer synthesis: an opportunity for green polymer chemistry," Chemical Reviews, vol. 109, no. 11, pp. 5288-5353, 2009.

[13] Y. H. Kim, E. S. An, S. Y. Park, J.-O. Lee, J. H. Kim, and B. K. Song, "Polymerization of bisphenol a using Coprinus cinereus peroxidase (CiP) and its application as a photoresist resin," Journal of Molecular Catalysis B: Enzymatic, vol. 44, no. 3-4, pp. 149-154, 2007.

[14] A. Claiborne and I. Fridovich, "Chemical and Enzymatic Intermediates in the Peroxidation of o-Dianisidine by Horseradish Peroxidase. 1. Spectral Properties of the Products of Dianisidine Oxidation," Biochemistry, vol. 18, no. 11, pp. 2324-2329, 1979.

[15] A. Claiborne and I. Fridovich, "Purification of the o-dianisidine peroxidase from Escherichia coli B. Physicochemical characterization and analysis of its dual catalatic and peroxidatic activities," The Journal of Biological Chemistry, vol. 254, no. 10, pp. 4245-4252, 1979.

[16] P. Di Gennaro, A. Bargna, F. Bruno, and G. Sello, "Purification of recombinant catalase-peroxidase HPI from E coli and its application in enzymatic polymerization reactions," Applied Microbiology and Biotechnology, vol. 98, no. 3, pp. 1119-1126, 2014.

[17] M. Zámocký, P. G. Furtmüller, and C. Obinger, "Evolution of structure and function of Class I peroxidases," Archives of Biochemistry and Biophysics, vol. 500, no. 1, pp. 45-57, 2010.

[18] M. Zámocký, B. Gasselhuber, P. G. Furtmüller, and C. Obinger, "Molecular evolution of hydrogen peroxide degrading enzymes," Archives of Biochemistry and Biophysics, vol. 525, no. 2, pp. 131-144, 2012.

[19] A. Díaz, P. C. Loewen, I. Fita, and X. Carpena, "Thirty years of heme catalases structural biology," Archives of Biochemistry and Biophysics, vol. 525, no. 2, pp. 102-110, 2012.

[20] R. Singh, B. Wiseman, T. Deemagarn, V. Jha, J. Switala, and P. C. Loewen, "Comparative study of catalase-peroxidases (KatGs)," Archives of Biochemistry and Biophysics, vol. 471, no. 2, pp. 207214, 2008.

[21] G. Regelsberger, C. Jakopitsch, M. Engleder, F. Rüker, G. A. Peschek, and C. Obinger, "Spectral and kinetic studies of the oxidation of monosubstituted phenols and anilines by recombinant Synechocystis catalase-peroxidase compound I," Biochemistry, vol. 38, no. 32, pp. 10480-10488, 1999.

[22] D. W. S. Wong, "Structure and action mechanism of ligninolytic enzymes," Applied Biochemistry and Biotechnology, vol. 157, no. 2, pp. 174-209, 2009.

[23] M. Kurisawa, J. E. Chung, Y. J. Kim, H. Uyama, and S. Kobayashi, "Amplification of antioxidant activity and xanthine oxidase inhibition of catechin by enzymatic polymerization," Biomacromolecules, vol. 4, no. 3, pp. 469-471, 2003.

[24] N. Ahmad and H. Mukhtar, "Cutaneous photochemoprotection by green tea: A brief review," Skin Pharmacology and Physiology, vol. 14, no. 2, pp. 69-76, 2001.

[25] S. J. Berger, S. Gupta, C. A. Belfi, D. M. Gosky, and H. Mukhtar, "Green tea constituent (-)-epigallocatechin-3-gallate inhibits topoisomerase I activity in human colon carcinoma cells,"
Biochemical and Biophysical Research Communications, vol. 288, no. 1, pp. 101-105, 2001.

[26] M. Demeule, J. Michaud-Levesque, B. Annabi et al., "Green tea catechins as novel antitumor and antiangiogenic compounds," Current Medicinal Chemistry-Anti-Cancer Agents, vol. 2, no. 4, pp. 441-463, 2002.

[27] D.-W. Han, M. H. Lee, H. H. Kim, S.-H. Hyon, and J.-C. Park, "Epigallocatechin-3-gallate regulates cell growth, cell cycle and phosphorylated nuclear factor- $\kappa$ B in human dermal fibroblasts," Acta Pharmacologica Sinica, vol. 32, no. 5, pp. 637-646, 2011.

[28] D.-W. Han, M. H. Lee, B. Kim, J. J. Lee, S.-H. Hyon, and J.C. Park, "Preventive effects of epigallocatechin-3- O -gallate against replicative senescence associated with p53 acetylation in human dermal fibroblasts," Oxidative Medicine and Cellular Longevity, Article ID 850684, 2012.

[29] M. Hosny and J. P. N. Rosazza, "Novel oxidations of (+)-catechin by horseradish peroxidase and laccase," Journal of Agricultural and Food Chemistry, vol. 50, no. 20, pp. 5539-5545, 2002.

[30] Y.-H. Lee, J. Kwak, H.-K. Choi et al., "EGCG suppresses prostate cancer cell growth modulating acetylation of androgen receptor by anti-histone acetyltransferase activity," International Journal of Molecular Medicine, vol. 30, no. 1, pp. 69-74, 2012.

[31] X. Carpena, W. Melik-Adamyan, P. C. Loewen, and I. Fita, "Structure of the C-terminal domain of the catalase-peroxidase KatG from Escherichia coli," Acta Crystallographica Section D: Biological Crystallography, vol. 60, no. 10, pp. 1824-1832, 2004.

[32] B. L. Triggs-Raine and P. C. Loewen, "Physical characterization of katG, encoding catalase HPI of Escherichia coli," Gene, vol. 52, no. 2-3, pp. 121-128, 1987.

[33] M. H. Lee, D.-W. Han, S.-H. Hyon, and J.-C. Park, "Apoptosis of human fibrosarcoma HT-1080 cells by epigallocatechin-3-Ogallate via induction of $\mathrm{p} 53$ and caspases as well as suppression of Bcl-2 and phosphorylated nuclear factor- $\kappa \mathrm{B}$," Apoptosis, vol. 16, no. 1, pp. 75-85, 2011.

[34] R. Pierini, P. A. Kroon, S. Guyot, K. Ivory, I. T. Johnson, and N. J. Belshaw, "Procyanidin effects on oesophageal adenocarcinoma cells strongly depend on flavan-3-ol degree of polymerization," Molecular Nutrition \& Food Research, vol. 52, no. 12, pp. 13991407, 2008.

[35] C. Agarwal, R. Veluri, M. Kaur, S.-C. Chou, J. A. Thompson, and R. Agarwal, "Fractionation of high molecular weight tannins in grape seed extract and identification of procyanidin B2-3,3/di-O-gallate as a major active constituent causing growth inhibition and apoptotic death of DU145 human prostate carcinoma cells," Carcinogenesis, vol. 28, no. 7, pp. 1478-1484, 2007. 


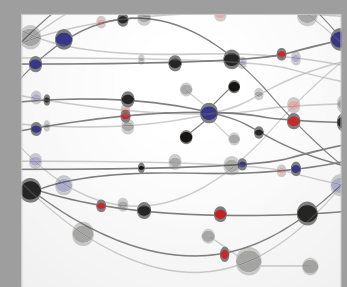

The Scientific World Journal
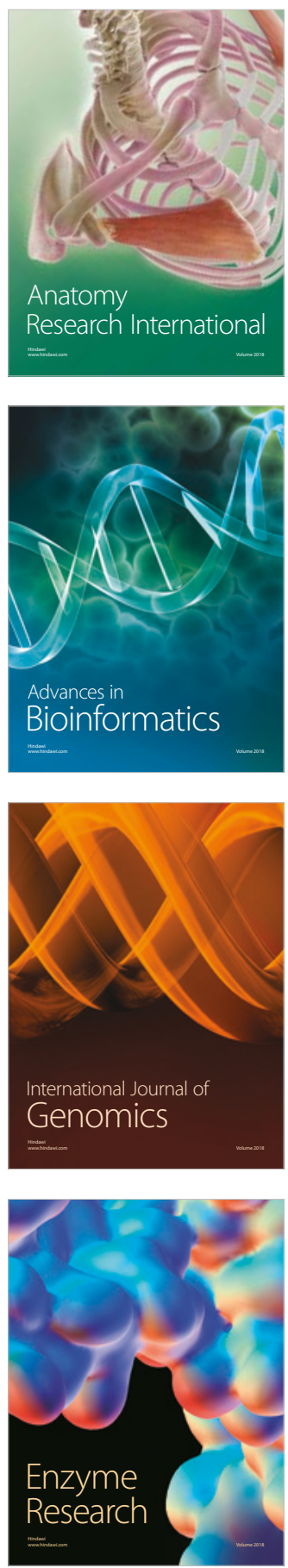
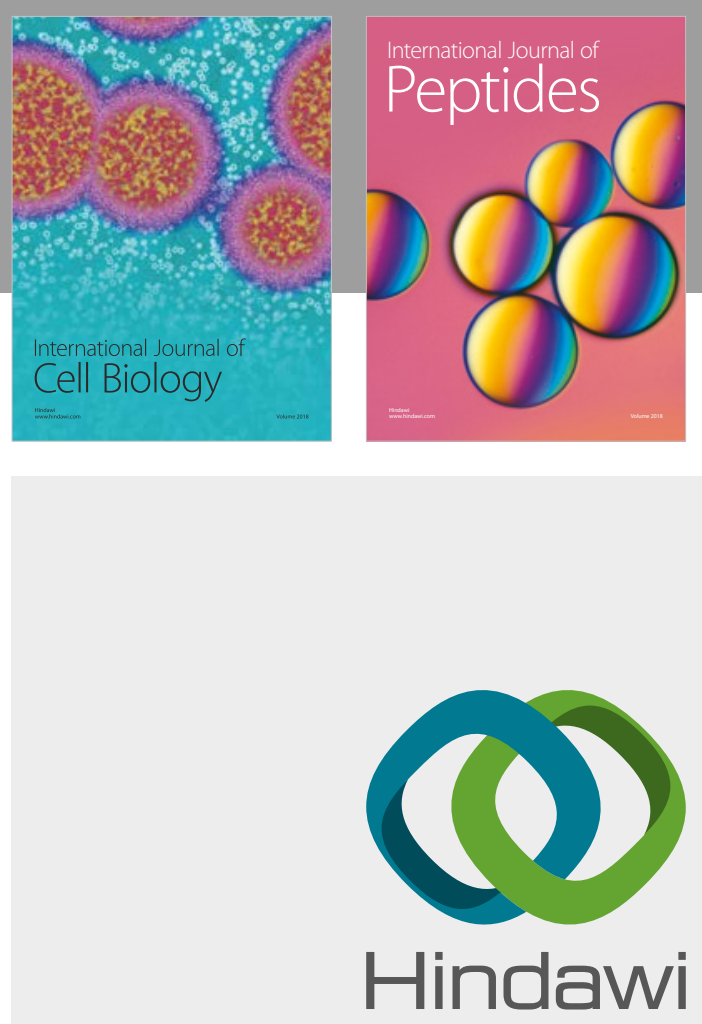

Submit your manuscripts at

www.hindawi.com
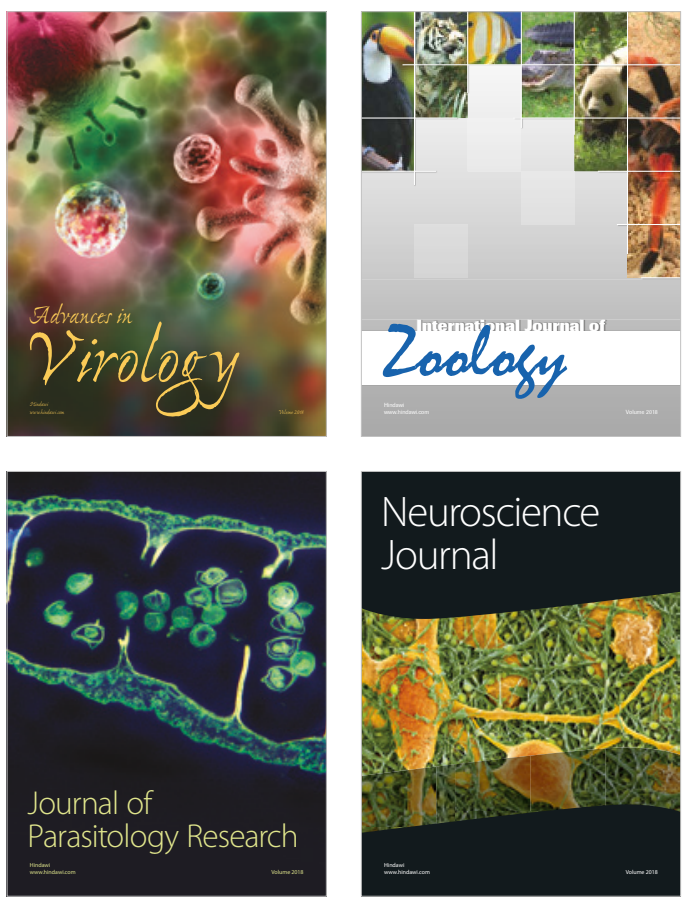
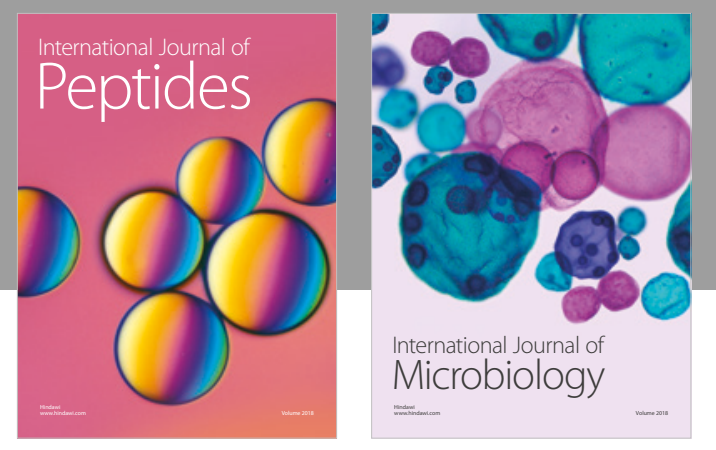

nternational Journal of Microbiology
Journal of
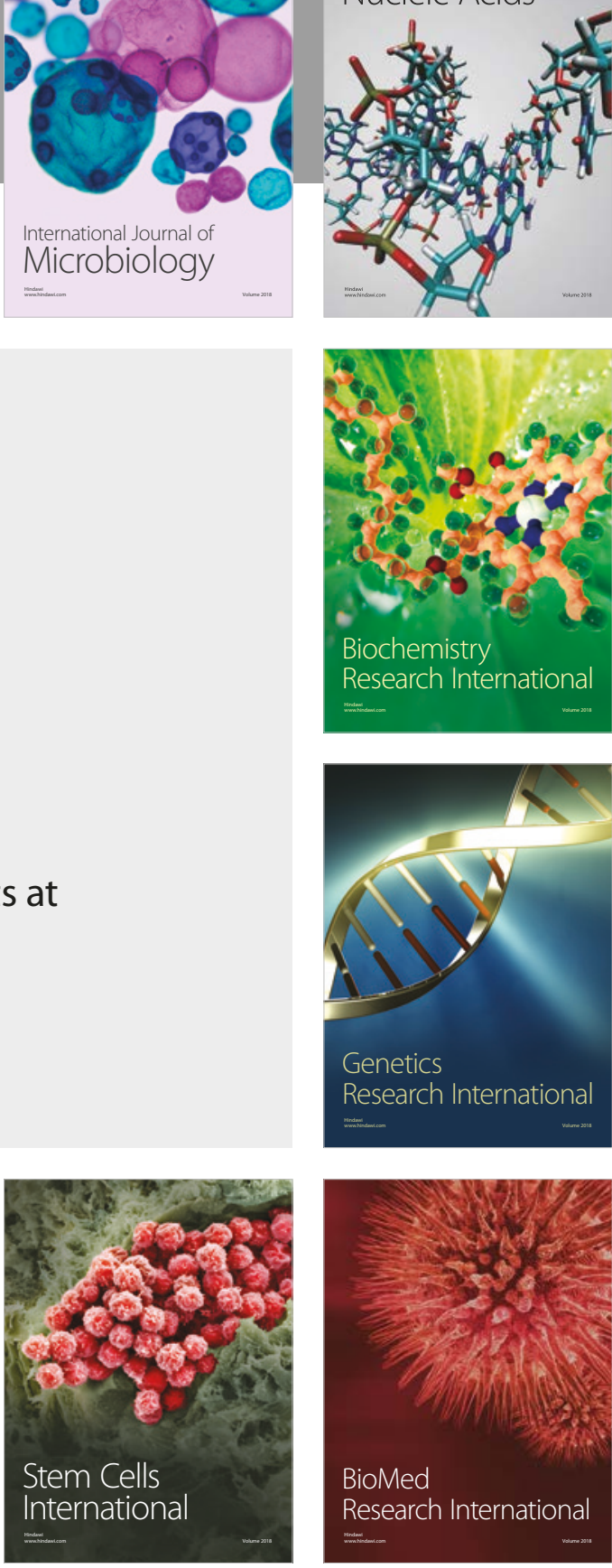
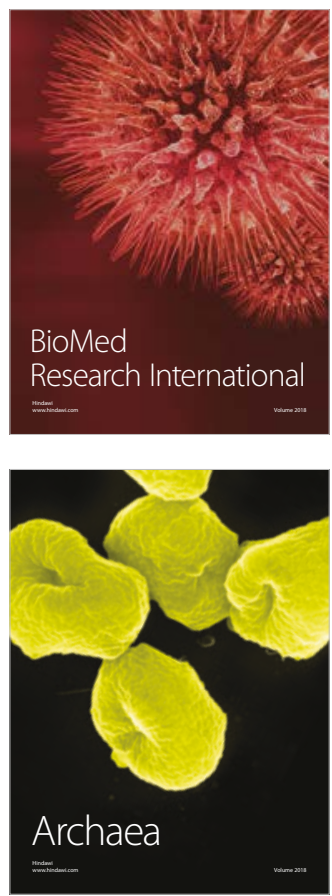